\title{
IN-VITRO STUDY TO EVALUATE THE COMPARATIVE ANTIMICROBIAL ACTIVITY OF ELA CHOORNA IN AMALAKI SWARASA, KADALI SWARASA AND NARIKELODAKA FOR SELECTED URINARY PATHOGENS
}

Nazneen A. Salam ${ }^{1 *}$, Priya.S ${ }^{2}$, Raiby Paul ${ }^{3}$

${ }^{1}$ PG Scholar, Department of Dravyaguna, Amrita school of Ayurveda, Vallikavu, Kollam, Kerala, India

${ }^{2}$ Professor and HOD, Department of Dravyaguna, Amrita school of Ayurveda, Vallikavu, Kollam, Kerala, India

${ }^{3}$ Associate professor, Department of Dravyaguna, Amrita school of Ayurveda, Vallikavu, Kollam, Kerala, India

Received on: 19/01/19 Accepted on: 22/02/19

\author{
*Corresponding author \\ E-mail: drnazneen89@gmail.com
}

DOI: 10.7897/2277-4343.100236

\begin{abstract}
Main objective of the study is to evaluate the comparative antimicrobial activity of Ela (Elettaria cardamomum) choorna in amalaki (Embilica officinalis) swarasa, kadali (Musaparadisiaca) swarasa and narikelodaka (Cocos nucifera) in selected UTI pathogens i.e. Escherichia coli, Proteus mirabiliss Klebsiella pneumoniae and Enterobacter aerogenes. In-vitro study was carried out in three methods-Agar Disc diffusion method, Agar well diffusion method and Serial dilution method. To determine the minimum inhibitory concentration (MIC) the agar disc diffusion method is not appropriate, as it is impossible to quantify the amount of antimicrobial agent diffused into the agar medium. So results were not accurate. So other two methods were used. Three drug combinations were tested in increasing concentrations against UTI pathogens. Drug combinations showed zone of inhibition against Klebsiella pneumonia. Among the three combinations of drug tested for antimicrobial activity Ela and Amalaki (40 g Ela in $200 \mathrm{ml}$ amalaki swarasa) combination is more effective against Klebsiella pneumonia in $20 \mu 1-7.5 \mathrm{~mm}, 40 \mu 19.5 \mathrm{~mm}$, in $60 \mu 111.7 \mathrm{~mm}$ inhibition noted. Serial dilution method was done for confirmation of antimicrobial activity of Ela and amalaki combination against Klebsiella pneumonia. In serial dilution, $30 \times 10^{3}$ colonies of Klebsiella pneumonia were reduced to $2 \times 10^{2}$ colonies.
\end{abstract}

Keywords: Mutrakrichra ,UTI, Ela, Amalaki, Kadali, Narikelodaka

\section{INTRODUCTION}

U.T.I is defined as the presence of pathogenic bacteria in significant colony counts in the bladder or upper urinary tract with associated clinico-pathological consequences ${ }^{1}$. It is a common bacterial infection managed in general medical practice and accounts for 1-3 \% of total consultations. Common microorganisms causing UTI are gram-negative bacteria, Escherichia coli- 75-90\%, others -Proteus mirabilis, Klebsiella pneumonia and Enterobacter aerogenes. Modern medical management of UTI includes mainly antibiotics which kill normal flora of intestinal bacteria along with infectious bacteria. Elimination of normal gut bacteria result in complications such as diarrhoea, digestive troubles, and constipation. The overuse of antibiotics in chronic UTI can lead to antibiotic resistance. Considering the above it is the need of the hour to search for alternative drugs from natural sources, which are effective, cheap and easily available with no adverse effects. In Ayurveda various drugs like Ela, Gokshura (Tribulus terrestris), Varuna (Crateva nirvula) are mentioned for the treatment of Mutrakrichra, most of them possessing antimicrobial effect. Different combinations of Ela mentioned in classical and contemporary texts of Ayurveda in context of Mutrakrichra Chikitsa. Ela and Amalaki swarasa, Ela and Kadali swarasa, Ela and narikelodaka mentioned in Ashtanga hridaya ${ }^{2}$, Charaka samhitha ${ }^{3}$ and Chikitsa manjari ${ }^{4}$ respectively has been taken for the present study.

Ela is a well-documented aromatic condiment in Indian medicine and tradition. Seeds are aromatic coolant, stimulant, carminative, digestive, stomachic, diuretic, cardio tonic, and expectorant ${ }^{5}$, these are useful in dyspepsia, anorexia, asthma, bronchitis, dysuria, renal and vesicular calculi etc. Recent researches showed antimicrobial, anti-inflammatory ${ }^{6}$, antihypertensive activity of Ela. ${ }^{7}$ Ela in combination with other drugs can enhance the properties by synergism. This study is to evaluate comparative antimicrobial effect of these combinations of Ela against Escherichia coli, Proteus mirabilis, Klebsiella pneumonia, Enterobacter aerogenes which are causative organism for UTI. The study has been designed as a pre-clinical in-vitro comparative study with Ela and Amalaki swarasa, Ela and Kadali swarasa and Ela and Narikelodaka.

\section{MATERIAL AND METHODS}

\section{Collection and preparation of drug}

Ela, amalaki, kadali removed of foreign matters and washed. Elettaria cardamomum was air dried; dehusked and seed powder was taken. Amalaki fruit and kadali kanda (rhizome) foreign matter was removed was crushed and $200 \mathrm{ml}$ of the juice was taken for each in a conical flask and different concentrations of Ela powder was added i.e. $10 \mathrm{~g}, 20 \mathrm{~g}, 40 \mathrm{~g}$ was taken. $20 \mathrm{ml}$ Narikelodaka was mixed with Ela choorna.

\section{Determination of Anti-microbial activity}

In-vitro study was carried out in three methods- Agar Disc diffusion method, Agar well diffusion method and Serial dilution method. To determine the minimum inhibitory concentration (MIC) the agar disc diffusion method is not appropriate, as it is impossible to quantify the amount of antimicrobial agent diffused into the agar medium. So results were not accurate. Other 
methods like Well Diffusion method were adopted. The bacteria procured from the Amrita school of microbiology were sub cultured and it was used for the study. The nutrient broth was prepared and to it a colony of bacteria from the culture is inoculated and kept for incubation. Mueller-Hinton agar (MHA) media was prepared and uniformly spread across the plate and allowed it to set in the laminar air flow. After $24 \mathrm{~h}$ the nutrient broth was taken and with the help of a swab the inoculum was taken and swabbed over the MHA. Then a hole with a diameter of 5-8 $\mathrm{mm}$ is punched aseptically with a sterile micro tip, 3 such wells are made and a volume of the extract solution i.e. $20 \mu \mathrm{l}$ is introduced into the well with the help of micropipette. The zone of inhibition was measured using a scale by noting the diameter. Among four organisms the inhibition was found in Klebsiella pneumoniae and maximum inhibition was seen in drug combination of Ela and Amalaki and this combination was tested by serial dilution technique for confirmation. $10 \mu \mathrm{l}$ of distilled water was taken in two boiling tubes and $100 \mu \mathrm{l}$ of the broth containing the organism (Klebsiella pneumoniae) is added, one of the boiling tubes is marked as control and other as test after the drug to the test-boiling tube and incubated for 1 hour. Six test tubes were taken and $9 \mathrm{ml}$ of normal saline is added to each of them. Two of them are marked as control $(\mathrm{C} 1, \mathrm{C} 2)$ with concentration of $10^{-1}, 10^{-2}$, dilution respectively and $1 \mathrm{ml}$ of the solution is taken from the control boiling tube and added to the test tube marked $10^{-1}$ and mixed well in vortex mixer, again $1 \mathrm{ml}$ of the solution was drawn from the tube with $10^{-2}$ dilution to $10^{-3}$ test tube and mix well. From each of the test tube a $20 \mu \mathrm{l}$ of the solution is taken and spread on a plate with nutrient agar and incubated for 16 hours. The same process was repeated on the test group. The results obtained after the incubation was noted.

Table 1: Results of Agar Well Diffusion method

\begin{tabular}{|c|c|c|c|c|}
\hline Name of the organism & Sample & \multicolumn{3}{|c|}{ Zone of inhibition } \\
\hline Escherichia coli & $E_{1}($ Ela and Amalaki ) & \multicolumn{3}{|c|}{ Nil } \\
\hline & $\mathrm{E}_{2}$ (Ela and kadali) & \multicolumn{3}{|c|}{ Nil } \\
\hline & $\mathrm{E}_{3}($ Ela and narikelodaka) & \multicolumn{3}{|c|}{ NIl } \\
\hline \multirow[t]{3}{*}{ Proteus mirabilis } & $\mathrm{E}_{1}($ Ela and Amalaki $)$ & \multicolumn{3}{|c|}{ Nil } \\
\hline & $\mathrm{E}_{2}$ (Ela and kadali) & \multicolumn{3}{|c|}{ Nil } \\
\hline & $\mathrm{E}_{3}$ (Ela and narikelodaka) & \multicolumn{3}{|c|}{ Nil } \\
\hline \multirow[t]{4}{*}{ Klebsiella pneumoniae } & \multirow[t]{2}{*}{$\mathrm{E}_{1}($ Ela and Amalaki $)$} & $20 \mu 1$ & $40 \mu 1$ & $60 \mu 1$ \\
\hline & & $7.5 \mathrm{~mm}$ & $9.5 \mathrm{~mm}$ & $11.7 \mathrm{~mm}$ \\
\hline & $\mathrm{E}_{2}$ (Ela and kadali) & $6.2 \mathrm{~mm}$ & $7.5 \mathrm{~mm}$ & $9 \mathrm{~mm}$ \\
\hline & $\mathrm{E}_{3}$ (Ela and narikelodaka) & $5 \mathrm{~mm}$ & $5.5 \mathrm{~mm}$ & $6 \mathrm{~mm}$ \\
\hline \multirow[t]{3}{*}{ Enterobacter aerogenes } & $\mathrm{E}_{1}($ Ela and Amalaki $)$ & \multicolumn{3}{|c|}{ Nil } \\
\hline & $\mathrm{E}_{2}$ (Ela and kadali) & \multicolumn{3}{|c|}{ Nil } \\
\hline & $\mathrm{E}_{3}$ (Ela and narikelodaka) & \multicolumn{3}{|c|}{ Nil } \\
\hline
\end{tabular}

Table 2: Results of Serial Dilution Method

\begin{tabular}{|c|c|c|c|}
\hline Name of Organism & Sample & Test & Control \\
\hline Klebsiella pneumoniae & $\mathrm{E}_{1}$ (Ela and Amalaki $)$ & $8 \times 10^{2}$ & $30 \times 10^{3}$ \\
\hline
\end{tabular}

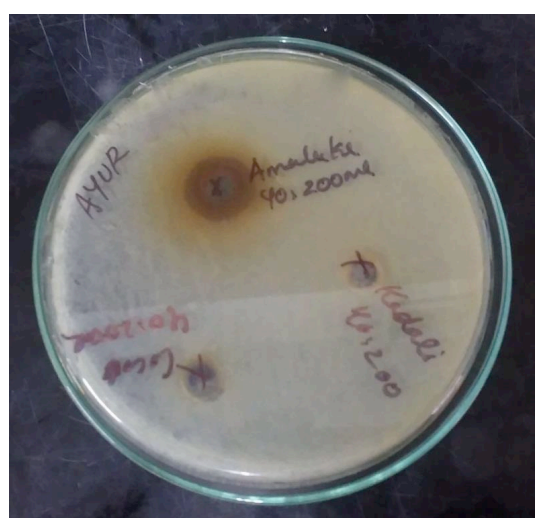

Figure 1: Zone of inhibition seen in well diffusion method

\section{RESULTS AND DISCUSSION}

Among the three combination of drug tested for antimicrobial activity Ela and Amalaki (40 g Ela in $200 \mathrm{ml}$ Amalaki swarasa) combination is more effective i.e. in $20 \mu \mathrm{l}-7.5 \mathrm{~mm}, 40 \mu \mathrm{l} 9.5$ $\mathrm{mm}$, in $60 \mu 111.7 \mathrm{~mm}$ inhibition noted. In serial dilution $30 \times 10^{3}$ colonies of Klebsiella pneumonia was reduced to $2 \times 10^{2}$ colonies.

The combination of Ela and Amalaki was found to be more effective against Klebsiella pneumoniae organism.

UTI is defined as presence of pathogenic bacteria in significant colony counts in bladder or upper UTI with associated clinic- pathogenic consequence. It is most common infection managed in medical practice; symptoms of urinary tract infection can be correlated to mutrakrichra. It is a pitta pradhanatridoshaja vyadhi with apanavayupritilomatha (apana vayu moving upwards). All the 3 drug combination of Ela exhibits antimicrobial activity against Klebsiella pneumonia in increasing concentrations. Ela and amalaki shows more antimicrobial activity. In serial dilution method this drug combination shows 1 log reduction of bacterial colonies. Mode of action of drug can be explained by Rasa panchaka. Ela possess madhura rasa (sweet taste), laghurukshaguna (light and dry quality), sheethavirya (cold in potency) and has vatahara properties. Ela due to vatahara properties causes apanavataanulomata (downward movement of 
vata) while amalaki which is amla (sour taste) pradhanapancharasa and sheethavirya helps in relieving symptoms of mutrakrichra due to pitta like daha (burning sensation). In modern medicine there is emerging problem of antibacterial resistance with almost all commonly used antibiotics with most of bacteria. Klebsiella pneumonia is most common bacteria next to Escherichia coli. Most of the Klebsiella pneumoniae strains are antibiotic resistant ${ }^{8}$. In modern view Bacteria causes inflammation of urothelium release toxins causing epithelial damage; so recurrent urinary tract infection may lead to cystitis. Recent researches shows Ela possess antiinflammatory properties and amalaki having immunomodulatory effect $^{9}$ so it can be given in recurrent infection associated with cystitis.

\section{CONCLUSION}

It can be ascertained from the study that Ela and amalaki combination shows more antimicrobial activity against UTI pathogen Klebsiella pneumonia compared to Ela and kadali and Ela and narikelodaka. Serial dilution method confirms antimicrobial activity. Ela having anti-inflammatory property and amalaki having immunomodulatory effect can be given in recurrent infection associated with cystitis. Efficacy of combination can be further substantiated by in-vivo trials.

\section{REFERENCES}

1. Siddharth N. Shah, YP Munjal, SK Sharma. Urinary tract infection, API Textbook of medicine, $9^{\text {th }}$ edition, Japee brother's Ltd; 2012. p. 1316.
2. Vagbhata, Prof. KR Srikantha murthy, Mutraghatha chikitsa, Astangahridaya English translation, edition, Choukambha Krishnadas academy, Varanasi; 2014. p. 373.

3. Charaka, Vaidya Yadavji trikamji, Trimarmeeya chikitsa, Chowkhambha Surbharathi Prakashan, edition; 2011. p. 573.

4. D. Shriman Namboodiri, Mootrakrichra Adhikara, Chikitsa manjari, $12^{\text {th }}$ edition, Vidhyarambham publications; 2007. p. 90.

5. PK Warrier, VPK Nambiar, C Ramankutty, Elettaria cardamomum, Indian medicinal plants (Vol.3), $6^{\text {th }}$ edition, Orient Longmann Private limited; 2006. p. 361.

6. Al Zuher h, el Sayeh, B Ameen. HA, al Shoora H, Pharmacological studies of cardamomum oil in animals, Pharmacol Res 1996; 34(1-2): 79-82.

7. Verma SK, Jain V, Katewa SS. Blood pressure lowering, fibrinolysis enhancing and antioxidant activities of cardamomum, Indian Biochem, Biophys; 2009; 46(6): 503-6.

8. CKJ Anandanarayanan, panicker, Enterobacteriaceae, textbook of microbiology seventh edition, Orient Longmann Pvt. Limited; 2007. p. 130.

9. RS Suja, AMC Nair, S Sujith, J Preethi, KK Deepa. Evaluation of immunomodulatory potential of Emblica officinalis fruit pulp extract in mice, Indian Journal of Animal Research 2009; 103,106.

\section{Cite this article as:}

Nazneen A. Salam et al. In-vitro study to evaluate the comparative antimicrobial activity of Ela Choorna in Amalaki Swarasa, Kadali Swarasa and Narikelodaka for selected urinary. Int. J. Res. Ayurveda Pharm. 2019; 10(2):53-55 http://dx.doi.org/10.7897/2277-4343.100236

Disclaimer: IJRAP is solely owned by Moksha Publishing House - A non-profit publishing house, dedicated to publish quality research, while every effort has been taken to verify the accuracy of the content published in our Journal. IJRAP cannot accept any responsibility or liability for the site content and articles published. The views expressed in articles by our contributing authors are not necessarily those of IJRAP editor or editorial board members. 